\title{
PUSAT SUMBER BELAJAR PAI DALAM DUNIA PENDIDIKAN; SEBUAH KAJIAN KRITIS DAN PENGEM- BANGANNYA
}

\begin{abstract}
Abstrak:
Oleh:

The more practical mastery of information technology has an impact on the choice

Asmuki of varied learning resources. Current education requires students to access all Hasanah the information needed to answer the problems they face and to improve their understanding of certain fields of science. Through the learning process, students

Email: asmuki@ibrahimy.ac.id can become empowered and creative people. The four pillars of learning, learning to know, learning to do, learning to be, learning to live together can be the basis hasanahthahir2@gmail.com of the process of empowering the lives of every student. In order to create creative learning activities, the learning resource center is present as a building designed in Fakultas Tarbiyah Universitas such a way as to store, care for, develop various learning resources for the benefit of Ibrahimy teachers and students, especially in accessing learning resources regarding Islamic education. To develop a learning resource center, at least one must pay attention to teacher creativity, paradigms, facilities, and targets as well as time and management competencies.

Keywords: Learning Resource, Center of Learning Resource, Development
\end{abstract}

\section{PENDAHULUAN}

Semakin kompleksnya pola kehidupan masyarakat pada era saat ini membuat dinamika kehidupan menjadi sangat kompleks pula. hal tersebut berimplikasi pada kebutuhan masyarakat yang tiada batasnya. Dalam memenuhi kebutuhan itu, dibutuhkan informasi yang cepat dan akurat. Sehingga peran informasi saat ini berada pada titik vital, yaitu sumber kebutuhan pokok manusia sehari-hari. Semakin informasi dibutuhkan oleh masyarakat, maka menciptakan informasi yang cepat, tepat dan akurat menjadi tantangan tersendiri bagi kalangan masyarakat di era milenial. Salah satu langkah dalam mewujudkan hal tersebut ialah bisa melalui pendidikan. Di sinilah peran pendidikan menjadi urgen dalam mengelola, mengatur, mencipta dan mengkonstruksi informasi. Karena analoginya ialah informasi yang bagus dapat tercipta oleh orang yang paham dan mengerti akan realitas yang sedang terjadi. Indikasinya adalah seseorang yang dapat dikatakan paham dan mengerti apabila seseorang tersebut telah menempuh sekian banyak proses belajar baik di sekolah maupun di luar sekolah.

Hal tersebut diatas mengindikasikan bahwa pendidikan sangatlah urgen untuk diselenggarakan. Saking pentingnya pendidikan, Plato mengungkapkan dalam buku yang berjudul Filsafat Pendidikan bahwa "menjadi suatu kewajiban tersendiri bagi negara untuk menyelenggarakan pendidikan". ${ }^{1}$ karena pendidikan merupakan senjata paling ampuh untuk merubah dunia. Dengan pendidikan maka sebuah peradaban akan tercipta dan melalui pendidikan bangsa dalam suatu negara akan sejahtera. Itu semua tak lepas dari tugas dan tanggung jawab pendidikan yang selaras dengan apa yang telah diamanatkan dalam UUD 1945 yakni mencerdaskan kehidupan bangsa. Bangsa yang sejahtera adalah bangsa yang cerdas, sebaliknya bangsa yang terpuruk adalah bangsa yang bodoh.

1 Jalaluddin dan Abdullah Idi, Filsafat Pendidikan: Manusia, Filsafat dan Pendidikan (Depok: Raja Grafindo Persada, 2016), 74 . 
Siti Murtiningsih mengatakan bahwa karena pendidikan masyarakat maju, begitu pula pendidikan yang maju hanya dapat ditemui dalam masyarakat yang maju. ${ }^{2}$ Jika bangsa ini ingin maju, maka langkah taktis yang harus ditempuh terlebih dahulu ialah memajukan pendidikan. Sebab pendidikan adalah jalan kunci menuju peradaban yang ideal dengan masyarakatnya yang maju. Jean Piaget mengatakan hanya pendidikan yang bisa mengantisipasi runtuhnya sebuah peradaban.

Oleh karena itu, usaha-usaha pendidikan sangat erat kaitannya dengan sumber belajar guna mengantisipasi runtuhnya peradaban dan membangun peradaban yang diinginkan. Melalui sumber belajar itulah maka proses pendidikan akan berjalan dengan seefektif mungkin. Pengetahuan dan informasi mudah didapat dengan tersedianya sumber belajar. Siswa lebih kreatif dalam mengisi pengetahuan di otaknya, tidak lagi melalui proses transformasi pengetahuan monoton yang hanya diberikan oleh guru untuk siswa.

Adanya sumber belajar ini juga berguna dalam mewadahi segala bakat siswa untuk dikembangkan. Siswa lebih aktif mencari sendiri tentang ilmu pengetahuan yang ia inginkan atau yang tidak dimengertinya. Bukan lantas serta-merta langsung menanyakannya kepada guru. Apabila hal tersebut dilaksanakan, tentu akan terjadi proses pembelajaran inquiri ditiap-tiap sekolah. Peran guru bukan lagi mengisi pengetahuan siswa, akan tetapi lebih pada mengobarkan api semangat siswa dalam menanamkan kesadaran tentang pentingnya belajar sepanjang hayat. Pada akhirnya, siswa bukan lagi makhluk yang hanya ketika disuruh saja ia akan belajar, melainkan menjadi makhluk pembelajar sejati.

Pentingnya terhadap sumber belajar tersebut harus diimplementasikan dalam bentuk yang nyata, bukan hanya sekedar menjadi verbalisme murni (kata-kata kosong) saja. Sehingga nantinya ada yang namanya pusat sumber belajar. Dimana sumber belajar ditempatkan pada satu titik pusat tertentu atau wadah tertentu berupa data, orang, atau benda sehingga dapat memberikan fasilitas belajar yang memadahi bagi siswa. Pusat sumber

2 Siti Murtiningsih, Pendidikan Sebagai Alat Perlawanan: Teori Pendidikan Radikal Paulo Freire (Yogyakarta: Resist Book, 2004), 11. belajar merupakan bentuk bangunan mulai dari yang sederhana sampai yang rumit dan lengkap, yang dirancang dan diatur secara khusus dengan tujuan menyimpan, merawat, mengembangkan, dan memenfaatkan koleksi sumber belajar dalam berbagai bentuknya baik secara indibvidual maupun kelompok. PSB di pandang sebagai suatu kegiatan yang terorganisasi, terdiri dari direktur PSB, staf, peralatan dan bahan-bahan pembelajaran yang ditempatkan dalam suatu lokasi yang mempunyai fasilitas khusus untuk perencanaan, pemmbuatan, penyajian, pengembangan dan pelayanan. ${ }^{3}$

Namun dalam mengembangkan pusat sumber belajar yang baik, butuh pemikiran yang serba ekstra dan tenaga sekuat kuda. Tidak segampang kita dalam membolak-balikkan telapak tangan. Oleh karena itu, perlu adanya sebuah upaya dalam mengidentifikasi hal-hal apa saja yang dibutuhkan dalam mengembangkan pusat sumber belajar. Hal tersebut akan dibahas pada point berikutnya berdasarkan mini research penulis dari hasil wawancara dan studi pustaka.

\section{PEMBAHASAN}

\section{Belajar Sebagai Pilar Utama dan Proses Pemberdayaan}

Banyak definisi belajar yang bisa kita temukan di berbagai literatur. Salah satu pengertian belajar yang paling umum dan disepakati oleh banyak pakar adalah berubahnya tingkah laku sebab adanya aktivitas berupa latihan dan pengalaman yang berkaitan dengan aspek kognitif, afektif serta psikomotorik. Pengertian ini nyaris tidak terbantahkan oleh beberapa pakar pendidikan, sehingga secara tidak langsung pengertian belajar secara proporsional adalah perubahan tingkah laku pada diri manusia.

Ketika seseorang dikatakan telah belajar maka implikasinya adalah tingkah laku pada diri individu itu yang harus mengalami perubahan. Eksistensi belajar dalam dunia pendidikan sangatlah penting dilaksanakan. Sebab jika ditinjau dari keinginan banyak para individu yang melaksanakan aktivitas belajar tiada lain untuk mentransformasi tingkah laku tidak baik menuju tingkah laku yang baik, atau dari

3 Indah Komsiyah, Belajar dan Pembelajaran (Yogyakarta: Teras, 2012), 45. 
suatu tahap tingkah laku yang baik menjadi tingkah laku yang lebih baik. Maka dari itu peran belajar sangat urgen dalam pendidikan karena bersinggungan langsung dengan upaya-upaya berubah atau tidaknya tingkah laku peserta didik. Hal ini diperkuat dengan statement Annurahman yang mengatakan bahwa esensi pendidikan yang sebenarnya adalah aktivitas belajar itu sendiri.

Supaya aktivitas-aktivitas belajar sesuai dengan rambu-rambu dan tujuan universal pembelajaran, maka terdapat empat pilar belajar sebagaimana yang telah dikeluarkan oleh UNESCO. Empat pilar belajar tersebut diantaranya adalah learning to know, learning to do, learning to live together, learning to be. Adanya empat pilar belajar ini mengindikasikan bahwa aktivitas belajar dapat ditinjau dari berbagai aspek, tidak terfokus pada satu aspek saja. Kajian pembelajaran menjadi semakin luas dan kaya akan tujuan. Dan panda intinya pendidikan bukanlah sekedar proses memindahkan tingkah laku dari sumber belajar kepada objek belajar.

Learning to know adalah sistem yang menuntut anak didik untuk mengetahui terhadap materi atau pelajaran yang telah dipelajarinya. Seorang peserta didik tidak hanya mendapatkan informasi dari pendidik tanpa ia pahami atau mengerti. Jadi seorang guru tidak lagi hanya menyandang sebuah pekerjaan simbolis saja, lebih dari itu seorang guru harus mampu mencerdaskan para peserta didik. Ketika telah mempunyai tugas mencerdaskan peserta didik, maka tidak jauh dari langkah awalnya yaitu memberikan pengetahuan serta bagaimana pengetahuan itu bisa dipahami oleh peserta didik nantinya.

Dengan learning to know, diharapkan bisa meminimalisir sistem pendidikan yang klasik menjadi sistem pendidikan yang lebih modernis. Oleh karena itu, nantinya tidak ada lagi seorang guru yang hanya memberi pelajaran atau pengetahuan secara percumacuma kepada peserta didik tanpa menghiraukan apakah pelajaran itu dimengerti, dipahami atau tidak oleh peserta didik.

Analoginya ibarat seorang pengembala sapi yang mempunyai beberapa sapi dikandangnya. Setiap waktu yang telah terjadwal, seorang pengembala ini pasti memberi makan beberapa sapinya dikandang. Dengan rumput yang non selektif ia berikan ke kandang sapi tersebut, tanpa ia memperhatikan apakah rumput yang ia berikan itu habis dimakan atau tidak? Apakah rumput yang ia berikan itu sesuai dengan selera sapinya atau tidak? Pengembala tersebut tidak menghiraukan itu semua, yang ada dibenaknya yang terpenting dia telah melaksanakan tugasnya yaitu memberi makan sapi-sapinya. Ia juga tidak mau tau apakah sapinya itu sudah kenyang atau tidak yang terpenting ia telah melaksanakan tugasnya.

Dari analogi tersebut di atas, bagaimana nantinya seorang guru yang masih menerapkan sikap seperti pengembala tersebut bisa diberantas. Sehingga pelajaran yang akan diberikan kepada peserta didik terselektif terlebih dahulu, akibatnya pelajaran itu sesuai dengan selera peserta didik. Ketika sudah sesuai dengan selera peserta didik, maka pelajaran itu pasti bersifat proporsional. Peserta didik akan lebih memahami pelajaran yang disampaikan oleh pendidik. Dan pendidik nantinya selalu mengevaluasi pembelajaran yang sesuai dengan peserta didik dan memberikan pemahaman yang berarti padanya. Nantinya tidak ada lagi penerapan classical education di beberapa satuan pendidikan.

Peserta didik dituntut bukan hanya bisa memiliki, menyimpan, mengingat dan mengetahui informasi sebanyak-banyaknya, akan tetapi peserta didik dituntut untuk memahami terhadap materi yang telah diterimanya. Kemampuan menangkap peluang untuk melakukan pendekatan ilmiah diharapkan bisa berkembang yang tidak hanya melalui logika empirisme semata, tetapi juga secara trasendental, yaitu kemampuan mengaitkannya dengan nilai-nilai spiritual.

Pilar kedua adalah learning to do jika diartikan ke dalam bahasa Indonesia memiliki makna belajar berbuat atau melakukan. Hal tersebut sebagai reaksi dari proses pembelajaran, di mana pserta didik telah memiliki bekal informasi dan pengetahuan yang banyak akan tetapi dituntut agar mampu mengamalkan dan melakukannya dalam praktek sehari-hari. Sehingga tidak ada kata-kata bahwa suatu ilmu tidak ada yang real dalam memecahkan masalah-masalah kehidupan. Siswa dilatih untuk mampu melakukan sesuatu dalam situasi nyata yang menekankan pada penguasaan keterampilan. Oleh karena itu, guru perlu mendesain proses belajar mengajar yang aplikatif, maksudnya menekankan 
pada keterlibatan siswa, baik fisik, mental, maupun emosionalnya. Hal ini bertujuan membentuk generasi muda yang terampil dalam berkomunikasi, bekerja sama, mengelola, dan mengatasi suatu konflik.

Learning to do merupakan sebuah konsekuensi dari learning to know, yang menekankan pada pengaplikasian ilmu yang telah diperoleh atau yang telah dipahaminya. Kelemahan model pendidikan dan pengajaran yang selama ini berjalan adalah pengajaran "teori" saja, dan masih dikatakan kurang dalam menuntun orang untuk melakukan "praktek". Leaning to do bukanlah hanya sebatas pembelajaran yang menumbuh kembangkan kemampuan berbuat secara mekanis dan keterampilan tanpa pemikiran. Melainkan yang diharap dalam konsep ini adalah bagaimana mendorong dan menuntun peserta didik untuk selalu belajar menumbuh kembangkan kerja. Juga bagaimana peserta didik bisa mengembangkan teori atau konsep. Learning to do tidak hanya tertuju pada penguasaan suatu keterampilan bekerja, tetapi secara lebih luas berkenaan dengan sebuah kompetensi atau kemampuan yang berhubungan dengan banyak situasi dan bekerja dalam tim.

Setelah learning to do ialah Leaning to be. Adapun learning to be jika diartikan ke dalam bahasa Indonesia memiliki makna belajar menjadi seseorang atau belajar demi masa depan. Konsep belajar ini menempatkan pendidik sebagai salah satu aktor pendidikan yang mempunyai tugas untuk memberi motivasi kepada peserta didik. Bagaimana nantinya peserta didik mempunyai semangat belajar yang tinggi, sehingga mempunyai cita-cita yang jelas pada masa depannya. Di situlah letak pendidikan yang ideal dan yang diharapkan oleh seluruh lapisan masyarakat.

Di samping itu, bagaimana peserta didik mengenali terlebih dahulu siapa dirinya. Melalui hal tersebut maka nantinya peserta didik akan menemukan jati diri, dan akan mempunyai sebuah paradigma baru yang teguh dan tak gampang goyah, karena peserta didik memperolehnya dari kesadaran diri. Juga pada akhirnya peserta didik diharapkan mempunyai tujuan yang jelas dalam proses kehidupannya di masa yang akan datang.

Masa depan adalah suatu hal yang sangat transendental. Pendidikan harus memperhatikan betul terhadap masa depan anak didiknya. Karena pendidikan adalah pedang untuk menumpas masa depan muram. Oeh karenanya konsep learning to be ini sangat penting untuk diimplementasikan dalam proses pendidikan. Lebih-lebih sebagai penguat dan pengokoh prinsip-prinsip pendidikan yang telah dirancang serta menjadi kesepakatan bersama.

Ketika masa depan telah diraih dengan baik, maka tentu langkah yang harus dipikirkan ialah bagaimana peserta didik atau seseorang dapat hidup bersama dengan anggota-anggota masyarakat lainnya. Hal ini juga didasari sebab manusia sebagai makhluk sosial. Dari hal tersebut, maka ada sebuah pilar yang bernama Learning to live together. Adapun learing to live together mempunyai makna dalam bahasa Indonesia yaitu belajar untuk hidup bersama. Sebagai manusia yang bercirikan makhluk sosial, maka manusia tak akan luput dari kebersamaan. Karena sejatinya manusia satu akan membutuhkan terhadap manusia lainnya. Hal itu pasti terjadi di manapun dan kapanpun, tak mengenal jarak dan waktu, sebabnya manusia pasti mempunyai suatu kebutuhan. Untuk memenuhi kebutuhannya itu, manusia tidak akan bisa melakukannya hanya dengan seorang diri saja, melainkan butuh orang lain dalam mencapainya.

Dalam konteks pendidikan, peserta didik diharapkan mampu bersosialisasi dengan baik dan berkomunikasi yang cakap dalam proses pendidikan. Hal ini dapat diimplementasikan dalam kegiatan pembelajaran, seperti belajar kelompok dalam kelas, menghargai pendapat teman, menerima pendapat teman yang berbeda, mengemukakan pendapat untuk membagi ide dan pengalaman dengan siswa lain.

Learning to live together ini mengajarkan seseorang untuk bisa hidup bermasyarakat dan menjadi manusia berpendidikan yang bermanfaat, baik bagi diri sendiri, masyarakat, dan seluruh umat manusia. Kesempatan berinteraksi dengan berbagai individu dan kelompok yang bervariasi akan membentuk kepribadian siswa untuk memahami kemajemukan dan melahirkan sikap-sikap positif dan toleran terhadap keaneka ragaman hidup dan perbedaan hidup.

Dengan hadirnya konsep learning to live together ini diharapkan dapat terwujud sikap kebersamaan hidup bersama, saling mengahargai, terbuka, 
memberi dan menerima yang dikembangkan di sekolah, menumbuhkan rasa memahami, menghargai dan menghormati orang lain. Siswa akan mampu menyadari adanya ketergantungan dan hubungan timbal balik antara manusia. Lebih dari itu juga diharapkan dapat terwujudnya adanya tujuan bersama menuju pada semangat kerja sama dan perdamaian demi kebaikan bersama.

Konsep Learning to live together ini sangat cocok bila diterapkan dalam sistem pendidikan Indonesia dan sekaligus menjadi sebuah bahan penguat yang sakral demi terwujudnya pendidikan yang baik dan ideal. Mengingat banyak orang yang berpendidikan dan mempunyai kecakapan ilmu yang tak bisa diragukan lagi keilmuannya, akan tetapi tidak bisa berkomunikasi dengan para masyarakat dan tetangga sekitar rumahnya. Ini menandakan bahwa terjadi sebuah problem dalam pendidikan di Indonesia. Oleh karena itu, belajar untuk hidup bersama penting dilakukan sebagai masyarakat Indonesia yang mempunyai semangat kekeluargaan, gotong royong, dan multi etnis.

Melalui adanya empat pilar tersebut di atas, jelas menempatkan peserta didik sebagai subjek pembelajaran. Pandangan-pandangan yang sebelumnya familiar mengartikan pendidikan sebagai proses pemindahan pengetahun dari pendidik ke peserta didik dapat teratasi dengan adanya pembelajaran yang berpusat pada peserta didik. Jadi, pendidik tidak lagi menjadi manusia yang maha tahu dalam suatu kelas pembelajaran, akan tetapi pendidik diharap dapat memberikan stimulus kepada siswa untuk mencari pengetahuan secara mandiri. Adapun pendidik dalam hal ini lebih mejadi fasilitator dalam mencapai tujuan pembelajaran tertentu.

Peserta didik bebas mengakses apa yang hendak mereka ingin ketahui. Tentu dalam upaya mengetahui sesuatu haruslah terdapat media atau sumber yang bisa menampung segala informasi. Sumber yang dapat menyediakan informasi-informasi terhadap kebutuhan peserta didik, disebut juga sumber belajar. Association Educational Communication and Technlogy mendefinisikan secara spesifik yakni segala hal yang dapat digunakan siswa untuk menambah pengetahuan dalam proses pembelajaran serta memfasilitasi siswa dalam mencapai tujuan pembelajaran tertentu baik berupa data, orang ataupun wujud lainnya, maka disebut sebagai sumber belajar. ${ }^{4}$ Melalui adanya sumber belajar ini maka pembelajaran yang cenderung searah, dalam artian bahwa pengetahuan hanya disampaikan oleh pendidik, maka nantinya dapat terentaskan menjadi pembelajaran dari segala arah yang berpusat pada peserta didik sebagai makhluk yang berdaya. Artinya berdaya adalah mampu mandiri dan menciptakan sesuatu yang bermanfaat bagi orang lain.

Maka sebab itu, pembelajaran haruslah mampu memposisikan peserta didik sebagai makhluk yang berdaya. Sebab memang tujuan pembelajaran yang sebenarnya adalah memberdayakan peserta didik sebagai manusia yang berdaya. Manusia yang berdaya adalah manusia yang tidak selalu tergantung pada orang lain namun bermanfaat kepada orang lain, serta manusia yang kreatif berpikir sehingga dapat menciptakan sebuah perubahan positif bagi dirinya dan masyarakat. ${ }^{5}$

\section{Sumber Belajar dan Pusat Sumber Belajar Pendidikan Agama Islam}

Dalam beberapa literatur telah banyak yang mengulas apa itu sumber belajar. Namun, secara umum sumber belajar memiliki definisi sebagai segala sesuatu yang dapat digunakan oleh siswa untuk meningkatkan pemahamannya serta digunakan sebagai fasilitas pembelajaran baik itu berupa data, manusia, atau benda. ${ }^{6}$ Di lain pihak banyak tokoh pendidikan yang menyebutkan bahwa segala sesuatu yang dapat memungkinkan siswa untuk belajar, maka disebut sebagai sumber belajar.

Esensinya sumber belajar diciptakan dalam rangka memberikan stimulus positif kepada peserta didik supaya aktif dalam melaksanakan kegiatan pembelajaran. Kemudahan mengakses sumber belajar dari mana saja dan sesuai kebutuhan dapat menciptakan iklim pembelajaran dari segala arah. Peserta didik menjadi kreatif berpikir dan menemukan berbagai ide baru yang nantinya dapat dijadikan dasar dalam mengembangkan sesuatu yang memiilki nilai mutimanfaat bagi masyarakat sekitar. Sebab itulah

4 Nunuk Suryani, dkk, Media Pembelajaran Inovatif dan Pengembangannya (Bandung: Remaja Rosdakarya, 2018), 16.

5 H.A.R. Tilaar, Paradigma Baru Pendidikan Nasional (Jakarta: Rineka Cipta, 2000), 21.

6 Nunuk Suryani, dkk, Media Pembelajaran Inovatif dan Pengembangannya (Bandung: Remaja Rosdakarya, 2018), 16. 
sumber belajar sangat urgen eksistensinya dalam dunia pendidikan.

Tentu adanya sumber belajar harus bisa dimanfaatkan oleh siapapun dalam melaksanakan aktivitas pembelajaran. Dalam hal ini termasuk peserta didik. Sumber belajar sepatutnya tidak boleh dikotomikan dengan kehadiran peserta didik sebagai subjek belajar, atau hanya peserta didik tertentu yang dapat menggunakan sumber belajar. Terbaiknya adalah bagaimana sumber belajar dapat dirasakan manfaat dan kegunaannya oleh semua individu yang sedang melakukan pembelajaran. Oleh karena itu seiring berjalannya waktu agar sumber belajar dapat memfasilitasi semua siswa saat belajar, maka terdapat dua jenis sumber belajar yang harus diketahui. Adapun sumber jenis sumber belajar tersebut adalah sebagai berikut:

\section{Resource by design}

Dalam hal ini, sumber belajar yang diterapkan telah terlebih dahulu dirancang sesuai kebutuhan pembelajaran. Artinya sumber belajar yang ada sengaja diciptakan atau dirancang untuk membantu peserta didik dan pendidik saat belajar. Contoh resource by design ini adalah handout, buku sumber, media informasi digital dan lain-lain.

\section{Resource by utilization}

Sumber belajar tipe ini tidak sengaja dirancang atau diciptakan terlebih dahulu, melainkan spontanitas ada dengan sendirinya. Dengan kata lain, sumber belajar jenis ini adalah segala sesuatu yang dapat dijadikan sumber belajar yang berada di area sekitar. Seperti contoh, tumbuh-tumbuhan, hewan, rumah kreatif, laut, gunung, langit dan lain sebagainya.

Sederhananya, kumpulan dari beberapa sumber belajar yang terintegrasi disebut juga sebagai pusat sumber belajar. Dikatakan sebagai pusat sumber belajar ketika didalamnya terkumpul berbagai varian sumber belajar menjadi satu kesatuan utuh sehingga dapat diakses atau digunakan oleh siswa secara praktis dan efisien. Pusat sumber belajar merupakan bentuk bangunan mulai dari yang sederhana sampai yang rumit dan lengkap, yang dirancang dan diatur secara khusus dengan tujuan menyimpan, merawat, mengembangkan, dan memenfaatkan koleksi sumber belajar dalam berbagai bentuknya baik secara indibvidual maupun kelompok. PSB di pandang sebagai suatu kegiatan yang terorganisasi, terdiri dari direktur PSB, staf, peralatan dan bahan-bahan pembelajaran yang ditempatkan dalam suatu lokasi yang mempunyai fasilitas khusus untuk perencanaan, pemmbuatan, penyajian, pengembangan dan pelayanan. ${ }^{7}$

D. Marimba menyatakan bahwa pendidikan agama Islam ialah sebuah upaya membimbing dan mengarahkan peserta didik baik dari segi jasmani ataupun rohani untuk mendapatkan berbagai macam pengetahuan yang berguna bagi keberlangsungan hidupnya sehingga tercipta kepribadian ideal menurut ukuran-ukuran Islam dan sesuai hukum-hukum Islam. ${ }^{8}$ Dalam rangka mencapai berbagai macam kompleksitas ilmu pengetahuan yang sesuai dengan rambu-rambu Islam, maka kehadiran pusat sumber belajar yang bernuansa Islam pun rentan diperlukan guna memfasilitasi peserta didik mengakses sumbersumber pengetahuan berbasis Islam tersebut.

Demikian pula, adanya pusat sumber belajar pendidikan agama Islam diharapkan dapat merangsang peserta didik agar menambah pengetahuannya secara kreatif dan mandiri sesuai dengan prinsip-prinsip Islam. Sehingga kajian-kajian ilmiah pada ranah Islam tetap terus berkembang pesat melalui kemudahan akses dalam memperoleh sumber-sumber belajar yang dibutuhkan. Hal ini selaras dengan tujuan pendidikan agama Islam yang dilontarkan oleh Athiyah AlAbrasy bahwa pendidikan Islam bertujuan untuk menyiapkan para pelajar dari segi profesional dan menumbuhkan spirit ilmiah pada pelajar.?

Keberadaan sumber belajar sudah tentu memiliki tujuan yang hendak dicapai. Tujuan pusat sumber belajar ialah untuk meningkatkan efektifitas dan efisiensi aktivitas pembelajaran antara peserta didik dan pendidik melalui upaya pengembangan instruksional. Pusat sumber belajar juga dapat memberikan multiopsional bagi pendidikan tradisionalis sehingga dalam penggunaannya

\footnotetext{
7 Indah Komsiyah, Belajar dan Pembelajaran (Yogyakarta: Teras, 2012), 45.

8 Abudin Nata, Ilmu Pendidikan Islam (Jakarta: Kencana, 2010), 14.

9 Abd. Aziz, Filsafat Pendidikan Islam: Sebuah Gagasan Membangun Pendidikan Islam, (Yogyakarta: Teras, 2009), 73.
} 
dapat mendorong pendidikan tradisionalis menuju modernis.

\section{Upaya Pengembangan Pusat Sumber Belajar dan Segala Hal yang Dibutuhkan}

Dalam mengembangkan pusat sumber belajar, mindset semua komponen dalam suatu institusi haruslah sejalan, dalam artian tidak terjadi kontradiksi antara satu dan yang lainnya. Salah satu mindset yang harus diperhatikan secara serius adalah rasa kecurigaan. Hal tersebut timbul akibat tidak adanya transparansi antara kepala sekolah, guru, staff dan siswa. Sehingga rentan terjadi kontradiksi antara beberapa pihak dalam sebuah institusi. Rasa saling mempercayai antara satu dengan yang lainnya perlu dijadikan mindset dasar dalam sebuah institusi pendidikan, khususnya terhadap pengembangan pusat sumber belajar.

Selain itu, yang tak kalah pentingnya adalah paradigma pengajaran. Pengajaran ini adalah kegiatan khusus yang dilakukan guru terhadap siswa. Guru sebisa mungkin mempunyai paradigma mengajar yang baik, salah satunya ialah rasa senang ketika memberikan pelajaran, masuk tepat waktu, memberikan pemahaman yang bermakna pada siswa bukan hanya sebatas memberikan materi ajar saja.

Selain paradigma pengajaran, ada juga paradigma pembelaajaran. Paradigma semacam ini tidak bisa dinafikkan dalam era revolusi industri 4.0 saat ini. semakin berkembangnya zaman, maka paradigma baru pembelajaran semakin terus berkembang keberadaannya. paradigma baru pembelajaran adalah tatacara bertindak atau melakukan proses pembelajaran dengan didasari oleh kegiatan berfikir didalam batas-batas tertentu supaya bisa berhasil dalam merubah tingkah laku manusia yang relatif menetap sesuai dengan kebutuhan siswa dan tuntutan zaman.

Hal tersebut di atas diperkuat dengan arti kata paradigma itu sendiri. Jika ditelisik dalam kamus bahasa Indonesia, paradigma mempunyai arti daftar contoh perubahan, tasrif dan bentuk kata. ${ }^{10}$ Pada dasarnya, perubahan bentuk kata secara garis besar sudah representatif dikatakan sebagai paradigma.

10 Moh. Kusnadi, Kamus Lengkap Bahasa Indonesia, (Surabaya: Cahaya Agency, tth), 353.
Dalam bahasa inggris paradigma adalah paradigm. Kata paradigm mempunyai arti model, pola, contoh. ${ }^{11}$ Tidak jauh berbeda dengan pengertian dari sudut pandang bahasa Indonesia, kata paradigma memiliki arti model atau tasrif perubahan.

Paradigma menurut Boglan dan Biklen, adalah kumpulan longgar dari sejumlah asumsi yang dipegang bersama, konsep atau proposisi yang mengarahkan cara berfikir dan penelitian. ${ }^{12}$ Jadi di sini Boglan dan Biklen lebih menekankan pada cara berfikir dan penelitian. Umumnya, paradigma memang banyak diartikan sebagai pola berpikir seseorang terghadap suatu realitas.

Di sisi lain, Baker mendefinisikan paradigma dalam "Paradigm: The Business of Discovering the Future" bahwa paradigma sebagai perangkat aturan (tertulis atau tidak tertulis) yang melakukan dua hal. Kedua hal tersebut ialah sebagai berikut:

Hal yang membangun atau mendefinisikan batas-batas.

Hal yang menceritakan kepada anda bagaimana seharusnya melakukan sesuatu didalam batas-batas itu agar bisa berhasil.

Ketika mindset dan paradigm sudah tertata dengan baik maka dalam mengembangkan pusat sumber belajar akan berjalan lancar. Kendalanya bisa jadi terminimalisirkan. Tentu dalam mengembangkan pusat sumber belajar tidaklah cukup pada aspek itu saja, melainkan butuh berbagai aspek yang nantinya bisa terintegrasi dalam menciptakan sumber belajar yang baik. Salah satu dari sekian banyak aspek tersebut ialah eksistensi seorang guru.

Guru adalah seseorang yang menjadi fasilitator dalam proses pembelajaran. Peserta didik dalam melaksanakan pembelajaran di sekolah didampingi oleh seorang guru yang bertugas mengarahkan, membimbing, menasehati, merangsang keilmuan, dan memberikan fasilitas pembelajaran.

Guru juga menentukan sistem atau metode pembelajaran yang baik terhadap kegiatan belajar

11 John M. Echols dan Hassan Shadily, Kamus Inggris Indonesia : An English-Indonesian Dictionary, Jakarta: Gramedia Pustaka Utama, 2005), 417.

12 Lexy J. Moleong, Metodologi Penelitiian Kualitatif (Bandung: Remaja Rosdakarya, 2017), 49. 
mengajar. Sehingga nantinya siswa lebih cepat memahami apa saja yang disampaikan oleh guru. Oleh karena itu, guru dituntut untuk kreatif dalam melaksanakan proses pembelajaran. Jika seorang guru bisa kreatif dalam melaksanakan pembelajaran, implikasinya siswa lebih nyaman dalam proses belajar. Kenyamanan belajar yang terjadi pada siswa akan berdampak pada pemahaman yang cepat dan utuh. Pendidikan modern saat ini memberikan alternatif yang baik terhadap sistem komunikasi antara guru dan siswa, yakni multiways communication. Sistem multiways communication ini adalah proses pembelajaran yang menekankan pada komunikasi interaktif antara guru dan siswa. ${ }^{13} \mathrm{Jadi}$, dalam proses pembelajaran siswa juga diajak berperan serta dalam mengembangkan dan menemukan ilmu pengetahuan. Seolah-olah ilmu pengetahuan tidak hanya dimiliki oleh guru seorang, dan guru bukan lagi subjek yang maha tahu untuk harus didewakan atau diimani segala titahnya. Melainkan merangsang adanya dialog kritis antara guru dan siswa.

Selain itu, guru juga harus mampu berbuat adil pada diri siswa. Semisal, guru tidak boleh mendikotomisasikan antara siswa yang satu dengan siswa yang lainnya, antara siswa yang bodoh dan siswa yang miskin, antara siswa yang terlahir dari keluarga ningrat dan siswa yang terlahir dari keluarga sederhana. Keadilan itu pun dapat dilihat dari upaya guru dalam memberikan penilaian secara objektif, bukan subyektif. Sehingga guru menilai dengan apa yang sebenarnya terjadi pada diri siswa atau realitas alamiah pada diri siswa itu sendiri. Guru juga harus mementingkan keinginan siswa dan segala kebutuhan siswa yang berkenaan dengan pengembangan kompetensi pedagogis.

Dalam beberapa literasi yang lainnya, guru adalah seseorang yang akan digugu dan ditiru. ${ }^{14}$ Oleh karena itu, guru di sini juga harus mempunyai sikap dan kepribadian yang baik. Karena dalam pendidikan, pengetahuan kognitif saja tidak cukup, melainkan harus diimbangi dengan karakter atau sikap yang terpuji. Mengapa demikian? Karena

13 Moh. Nawafil dan Junaidi, "Revitalisasi Paradigma Baru Dunia Pembelajaran yang Membaskan", Jurnal Pendidikan Islam Indonesia, vol. 4, No. 2, (April, 2020), 217.

14 Binti Maunah, "Implementasi Pendidikan Karakter Dalam Pembentukan Kepribadian Holistik Siswa", Jurnal Pendidikan Karakter, Vol. 5, No. 1, (April, 2015), 92. sudah banyak kita temukan orang-orang yang pintar lulusan universitas ternama dengan segudang ilmu pengetahuannya malah mejadi maling papan atas. Hal ini sudah mengindikasikan karakter atau sikap religius sangat urgen untuk ditanamkan dalam diri siswa sejak dini.

Tentu sebelum menanamkan kompetensi karakter yang ada pada diri peserta didik, guru harus mempunyai karakter yang baik terlebih dahulu. Lalu bagaimana mungkin seorang guru akan menanamkan karakter yang baik pada diri siswa sementara karakter guru tersebut cacat atau sakit. Hal tersebut diperkuat dengan pemberitaan yang viral di media masa bahwa banyak oknum-oknum pendidik yang mencabuli para siswinya. Hal ini mengindikasikan bahwa terdapat beberapa oknum guru yang cacat karakter. Oleh karena itu sebelum menjadi guru, hendaknya karakter seorang guru harus baik terlebih dahulu.

Guru merupakan suatu elemen yang berperan aktif dalam mengembangkan proses pembelajaran. Kreativitas guru juga diperlukan guna merangsang semangat belajar sehingga dapat melestarikan nilainilai islami yang telah tertanam dalam diri peserta didik. ${ }^{15}$ Sekolah sebagai pusat sumber belajar, akan tetap kokoh apabila proses pembelajaran didalamnya berlangsung secara efektif. Dan proses pembelajaran ini sangat dipengaruhi oleh eksistensi guru dalam mengkonsep kerangka pembelajaran yang baik dan kekreatifan guru dalam mengolah pembelajaran di dalam kelas.

Selain eksistensi guru, waktu juga sangat diperlukan dalam upaya-upaya mengembangkan pusat sumber belajar. Waktu yang banyak atau katakanlah proporsional sangat dibutuhkan dalam pendidikan. karena kegiatan belajar mengajar tidak bisa lepas dari waktu yang dibutuhkan. Dalam artian kegiatan belajar mengajar bisa optimal jika waktu yang disediakan proporsional, tidak kurang dari standard. Bila waktu yang diberikan dalam kegiatan belajar mengajar kurang, maka kendala yang terjadi adalah terhambatnya tujuan pembelajaran yang telah dirancang sebelumnya. Hasil belajarnya pun tidak akan sebaik yang diperkirakan.

15 Ahmad Baihaki, "Memotivasi Siswa Untuk Belajar Dengan Variasi Metode dan Penerapan PAIKEM", Jurnal Edupedia, Vol. 4, No. 2, (Januari 2020), 49. 
Berkaitan dengan waktu pembelajaran, menteri pendidikan mengeluarkan kebijakan alternatif yaitu full day school. Hal ini merupakan siasat atau strategi untuk mengefektifkan waktu pembelajaran yang maksimal di sekolah. Sehingga pada nantinya sekolah terus melahirkan generasi-generasi yang siap dan peka dalam menghadapi tantangan globalisasi, westernisasi dan lain sebagainya.

Dengan mengoptimalisasikan waktu, maka secara tidak langsung sara dan prasaran yang disediakan di sekolah dapat dimanfaatkan seefektif mungkin dalam menyokong kegiatan proses pembelajaran. Sekolah dapat dikatakan baik bila sarana dan prasarana yang terdapat dalam sekolah terlengkapi dengan baik. Sebab arana dan prasarana sekolah bisa menunjang terhadap kegiatan pembelajaran siswa. Yang awalnya proses transformasi materi pembelajaran dirasa sukar, akibat adanya sarana dan prasarana maka materi pembelajaran dapat teratasi dengan mudah. Sebab adanya sebuah mediasi yang bisa menjadi perantara bagi guru dan siswa untuk mencapai target pembelajaran. Eksistensi sekolah menjadi lebih bermakna jika didukung dengan sarana dan prasarana sekolah yang memadai. Berikut sarana dan prasarana sekolah yang perlu diperhatikan secara khusus.

\section{Kelas/Gedung Sekolah}

Kelas merupakan wadah atau tempat bagi siswa untuk belajar secara sistematis dan berjenjang. Di dalam kelas ini siswa bisa belajar dengan konsentrasi.

\section{Media Pembelajaran}

Dalam mewujudkan proses pembelajaran yang menyenangkan dan mudah dipahami oleh siswa, maka kehadiran media pembelajaran sangat diperlukan sekali. Seperti contoh papan tulis, lcd proyektor, laptop, komputer, mesin cetak, dan lain sebagainya.

Untuk menunjang pengetahuan siswa dalam mengakses sumber belajar, maka perpustakaan sangat urgen kehadirannya dalam sebuah institusi sekolah. Perpustakaan berfungsi untuk suatu wahana yang digunakan oleh siswa dalam mengembangkan ilmu pengetahuannya selain di dalam ruang kelas. Jadi diharapkan siswa mempunyai cakrawala ilmu pengetahuan yang luas melalui sumber-sumber bacaan yang tersedia dalam perpustakaan. Salah satu hal yang paling penting dalam perpusatakaan adalah tersedianya buku-buku referensi yang up to date.

Selain buku, kehadiran pustakawan sangat penting untuk mengelolah perpustakaan dengan baik. Hadirnya pustakawan atau pengurus perpustakaan ini bisa membuat mekanisme kegiatan perpustakaan menjadi tersistematis. Sehingga buku-buku didalamnya tidak mudah hilang. Kegiatan didalamnya hanya dipergunakan secara khusus untuk keperluan membaca dan mengembangkan ilmu pengetahuan. Jauh dari bising, ramai dan segala macam. Sehingga siswa bisa fokus dalam mengeksplorasi segala resource yang dibutuhkan untuk menambah pengetahuan yang dimiliki.

Di perpustakaan juga harus tersedia media pembelajaran siswa. Seperti komputer, notes, pensil dan lainnya. Perpustakaan yang ideal atau yang sempurna ialah perpustakaan yang bisa membuat siswa nyaman belajar dan betah berlama-lama membaca buku di perpustakaan.

Tentu semua orang bisa menyakini bahwa sekolah akan mencapai tampuk kejayaannya bila siswasiswinya melek ilmu pengetahuan dan tekhnologi. Salah satu caranya ialah dengan menyediakan sumber belajar yang memadahi. Sumber belajar tersebut bisa dikategorikan sebagai buku ataupun internet. Buku penting peranannya dalam membuka cakrawala berpikir para siswa menjadi lebih luas dan melek IPTEK. Jikalau perlu buku untuk siswa harus gratis, dalam artian siswa tidak perlu lagi membayarnyam melainkan sudah dibelikan atau difasilitasi oleh sekolah melalui perantara dana Badan Operasional Sekolah.

Buku merupakan sumber utama penunjang pengetahuan bagi siswa. Buku juga menjadi sumber pengetahuan yang bisa dijadikan alat bagi siswa untuk belajar secara mandiri, tanpa bantuan dari guru. Dalam kegiatan belajar mengajar guru juga perlu merujuk kepada buku-buku sumber agar khazanah pengetahuan siswa lebih mendalam. Jikalau perlu sampai pada akar-akarnya.

Untuk menunjang berpikir siswa, maka internet pun perlu disediakan dalam proses pembelajaran yang terjadi di sekolah. Mengingat 
saat ini manusia berperang informasi dan digitalisasi. Siapa yang banyak mendapat informasi, maka dia bisa menguasai perkembangan ilmu yang semakin tak terbatas oleh geografis kenegaraan. Selain itu, guru perlu hadir juga di tengah-tengah siswa dalam memberikan pengetahuan yang bersifat membimbing, mengarahkan, memantau dan lain sebagainya.

Dalam mengembangkan sekolah dengan baik, khususnya upaya dalam mengembangkan pusat sumber belajar juga perlu strategi yang matang sesuai dengan apa yang telah dijadikan tujuan dasarnya. Melalui strategi, yang mulanya mencapai tujuan dirasa agak susah, akan menjadi lebih mudah. Selain itu, tanpa kita bantah bahwasanya segala kegiatan yang terjadi di sekolah pasti sangat banyak dan kompleks. Oleh karenanya kepala sekolah juga harus pandai dalam memanage segala kegiatan sekolah. Sehingga nantinya, segala kegaiatan dapat berjalan secara efektif dan efisien.

\section{SIMPULAN}

Dari berbagai penjelasan di atas, maka dapat disumpulkan bahwa belajar adalah esensi dari pendidikan. Sebab melaui belajar, manusia akan diberdayakan kehidupannya. Terdapat empat pilar pembelajaran yang juga sangat penting dipahami oleh setiap insan pendidikan, empat pilar tersebut adalah learning to know, learning to do, learning to be, learning to live together. Empat pilar tersebut dapat menjadikan peserta didik menjadi manusia yang seutuhnya. Selain itu, juga terdapat sumber belajar yang memiliki fungsi sebagai pendongkrak pengetahuan peserta didik serta merangsang terjadinya proses pembelajaran yang positif. Segala hal yang dapat memfasilitasi peserta didik untuk belajar dan juga untuk menambah pengetahuan peserta didik baik berupa alat, benda, insan, dan lain-lain, disebut sebagai sumber belajar.

Pusat sumber belajar adalah sebuah bangunan yang dirancang sedemikian rupa dalam rangka untuk menyimpan, merawat, mengembangkan segala sumber belajar sehingga dapat dirasakan segala manfaatnya secara pribadi ataupun kolektif. Adanya pusat sumber belajar pendidikan agama Islam diharapkan dapat merangsang peserta didik agar menambah pengetahuannya secara kreatif dan mandiri sesuai dengan prinsip-prinsip Islam. Sehingga kajian-kajian ilmiah pada ranah Islam tetap terus berkembang pesat melalui kemudahan akses dalam memperoleh sumber-sumber belajar yang dibutuhkan. Mengembangkan pusat sumber belajar, banyak hal yang harus diperlukan, salah satunya ialah dengan mengedepankan kompetensi guru, mindset, kompetensi pengelolaan, sarana dan prasarana, time, dan lain sebagainya.

\section{DAFTAR PUSTAKA}

Aziz, Abd. Filsafat Pendidikan Islam: Sebuah Gagasan Membangun Pendidikan Islam. Yogyakarta: Teras, 2009.

Baihaki, Ahmad. "Memotivasi Siswa Untuk Belajar Dengan Variasi Metode dan Penerapan PAIKEM", Jurnal Edupedia, Vol. 4, No. 2, (Januari 2020).

Echols, John M. dan Hassan Shadily. Kamus Inggris Indonesia : An English-Indonesian Dictionary, (Jakarta: Gramedia Pustaka Utama, 2005.

Jalaluddin dan Abdullah Idi. Filsafat Pendidikan: Manusia, Filsafat dan Pendidikan. Depok: Raja Grafindo Persada, 2016.

Komsiyah, Indah. Belajar dan Pembelajaran. Yogyakarta: Teras, 2012.

Kusnadi, Moh. Kamus Lengkap Bahasa Indonesia. Surabaya: Cahaya Agency, tth.

Maunah, Binti. "Implementasi Pendidikan Karakter Dalam Pembentukan Kepribadian Holistik Siswa", Jurnal Pendidikan Karakter, Vol. 5, No. 1, (April, 2015).

Moleong, Lexy J. Metodologi Penelitiian Kualitatif. Bandung: Remaja Rosdakarya, 2017.

Murtiningsih, Siti. Pendidikan Sebagai Alat Perlawanan: Teori Pendidikan Radikal Paulo Freire. Yogyakarta: Resist Book, 2004.

Nata, Abudin. Ilmu Pendidikan Islam. Jakarta: Kencana, 2010.

Nawafil, Moh. dan Junaidi. "Revitalisasi Paradigma Baru Dunia Pembelajaran yang Membaskan", Jurnal Pendidikan Islam Indonesia, vol. 4, No. 2, (April, 2020). 
Suryani, Nunuk., dkk. Media Pembelajaran Inovatif dan Pengembangannya. Bandung: Remaja Rosdakarya, 2018.

Tilaar, H.A.R. Paradigma Baru Pendidikan Nasional. Jakarta: Rineka Cipta, 2000. 